\title{
Diketopiperazin 體ノ抗原性二就テ
}

（昭和 14 年 5 月 5 日受付)

（本論交ノ要旨八昭和 6 年及ビ昭和 11 年 4 月 /聯合微生物學會デ演述シタ）

日本瀜科大學細菌學教室

中 村 敬 三

\section{緒㝘}

叒疫學. 血清學, 領域二於ヶル研究ハ固ヨリ多岐廣沉デアルガ.ソソ中二就テ近年 特二化學的見地カラ系統的二研究艺レ來ツタモノ八. 抗原. 抗原性乃至抗原八特異性 ナドニ關スル部門デァラウ。

扠テ是レ等二關スル多クノ精細ナル研究カラシテ. 抗原性二モ抗原機能（生體內ニ 於テ特異抗體き產生セシムル抗原ノ能力) 卜抗原作用 (試驗管內二於テ抗原抗體反應 惹起七シムル抗原ノ特異的作用)卜ノ分割シ得ル二方面がアルコトガ明ニセラレ．從 ツテ抗原トシテノ資格アル物質モ此, 見地ヨリス、バ，蛋白質．含水炭素. 類脂體, 三部門ニ瓦ルコトモ制ツテ來タ。

然シナガラコレラノ物質,總テガ埧二抗原性ノ兩方面タ具備セル完全抗原ト見做サ ル可キモノデアルカ。トイフ問題ニナルト，モノニ依ツテハ今日佾ホ相當議論ノ餘地 モアル樣二見受ケラレル。

唯ダ其ノ中二就テ蛋白質二屬スルモノハ何ト謂ツテモ完全抗原タル資格ノアルモノ ガ大多數ト見テ良イ。從ッテ完全抗原ノ對象トシテ夙二蛋白質ガ擇バレ.コレニ就テ 抗原性ノ研究が專う行ハレテ來タノモ理ノ當然デアル。所が化學ノ領域二於广モ。蛋 白質ノ構造ナルモノガ最モ厄介ナ問題デアリ．容易二結着シサウモナイ有樣デアルカ ラ.勢七免疫學二於ヶル抗原性, 問題モ兔角明暸キ缺クノハ止ムキ得又所卜思フ。

抑 々 蛋白質ノ構造二關ス几學說ハ. Emil Fischer 以來 Polypeptid 連鑽ガソノ根 幹キナスモノト見做サレテ來タ。尤モソノ間多少ノ變更試にタモノハアッタガ. ソ レトテモ Polypeptid 連鎖二枝キ附ケ. 又八所々ニ大キナ輪狀ノ構造き畫シ. 或ハ又 連鎖中二Amino-酸ノシナラズ.ソノ無水物ガ挾ツテ居ルコトキ想像シテ居ルニ過ギ ナイモノデ. 要スルニ Fischer , 學說,圈外ニ出ヅルモノデハナカッタガ. 其ノ後 
Abderhalden, Herzog, Bergmann ノ諸氏ハAssoziation 說キ提出シ。蛋白質キ以 テ Amino-酸無水物ノ重合體ト見做スヤウニナリ，學界ノ耳目チ唒動シタガ: 最近デ ハAstbury (1933) ノ說ヤ。 又ソレチー層數衍シタ Wrinch 人 Cyclol 說 (1937)ナド ガ擡頭シテ來テ居ル有樣デアル。

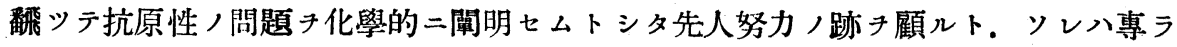
Polypeptid 連鍞說ノ䢔奉サレテ居ツタ時代ノコトデアッタカラ. 蛋白質分解ノ終末 產物タル Amino-酸ノ抗原性ガ先ヅ姐上ニノボセラレタ譯デアル。'然シ結局蛋白質構 成，基本物質二八抗原性ガナイト云フ結論ニナッテアッタ。

然ラバ蛋白質ハソノ分解過程ノ何所カデ抗原性キ失フコトニナル譯デアルガ.ソレ ガ果シテ如何ナル構造ノ所デアルカト云フ問題ニナルト．コレハ輕々二斷定キ下シ得 ヌ事情ニアル。ソコデ先人八抗原性ナキAmino-酸カラPolypeptid，連鑍き作ツテ. 抗原性子化學的二合成シャウトシタ。コレニ關シテハ.Zunz 及ビソノ他ノ學者ノ著 明ナ報告モアルガ. 矢張り今日ノ見地カラ嚴密二批制スレバ、ソノ䱔認容スル譯ニモ 行カズ. 結局不成功二終ツテキルモノト見ルノガ穻當デアラウト考へル。

双テ大正ノ末年カラ昭和ノ初頭ニカケテハ。丁度 Assoziation 說ノ盛ナ時代デアッ テ. 蛋白質ノ構造八基體分子ノ重合又ハ集團トィフ事デ說明セラレントシ。コノ基本 體トシテ種々ノAmino-酸ノ環狀無水物。主トシテ Diketopiperazine 類が擧ゲラレ タノデアル。

ソコデ蛋白質ノ抗原性二關スル問題モ. 兔モ角此,見地カラモ一應檢討シ置ク必要 ガアルト考へタノデ，當時著者ハ蛋白體カラ Diketopiperazin ト想定セラレルモノ ヨ作リ、ソレノ抗原性キ研究シテ。ソノ結果キ昭和 6 年 4 月八聯合微生物學會デ報告 シタノデアル。尤モ其ノ當時, Assoziation 說ハカナリ極端デアッタカラ. 其後及 種々，假說ガ現ハレテ來タ次第ナノデァルガ. 然シナガラ元來蛋白分解ノ終末産物卜 シテ得ラレタ物質デ. 構造化學上確然タルモノハ Amino-酸. Peptide 及ビ Diketopiperazin ナノデァルカラシテ. 此ノ最後, Diketopiperazin 二關シテモ. 其ノ血 清學的意義き明暸ニシテオクコトハ. 冕疫學ノ基本知識トシテ必要ナコトト信シタ， デ. 昭和 10 年ニハ更二研究室デ化學的純粹二作製シタ Diketopiperazin キ以テ. 本 問題き的究シ.ソノ結果タ翌 11 年 4 月ノ第 10 问聯合微生物學會デ報告シタノデア r。

今コレラノ成績タ一括シテ以下簡單二記載シ度イト思フ。 


\section{第一章 蛋白犋ノ「グリセリン」熱分解ニ传りテ得ラレタル Diketopiperazin 體/抗原性二就テ}

笼二用ヒタ抗原蛋白八馬血清蛋白及ビ Kasein, Merk デアッタ。 先ヅ馬血清蛋白二關スル賽驗キ述ベルコトニスル。

最初血清蛋白 乾燥狀態二得ル第メ二. 健康馬血清 $200 \mathrm{ccm}$ 二蒸餾水 $100 \mathrm{ccm}$ チ和 シ。ソコ一硫酸安門 $226 \mathrm{~g}$ チ良ク混和シ。翌朝迄水宝二放置シタ後コレチ滤過シ。 6 個，Fischblase 二分割シテ無菌的操作ノ下 $=4$ 日間透析正行七. $\mathrm{NH}_{4}$, ノ全ク消失 セルコトキ確メル。コノ時ソノ總量ハ約 $550 \mathrm{ccm}$ 二達シテ居ツタ。次デ $40^{\circ} \mathrm{C}$ 眞空乾 燥器中二納メ. 同時 $=\mathrm{CaCl}_{2}$ チ作用セシメ.カクテ 3 書夜デ全ク乾燥セルコトチ確メ タ。科量スルニ約 $8 \mathrm{~g}$ デアッタガ操作中相當量ノ損耗ハアツタモノト思ハレル。

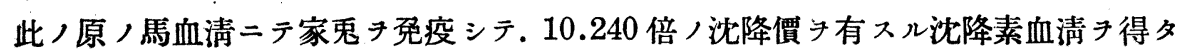
ガ. コj抗馬家鬼血清八又乾燥血清丹生理的食監水二テ $8 \%$ 割合二溶解シタモノニ 對シテモ。ソノ 5.120 倍迄沈降反應陽性デアッタ。

カ、ル乾燥血清 $5 \mathrm{~g}$ ト「グリセリン」50 ccm トチ. 逆流冷却裝置キ備へタ圓底コルベ ン中ニ入レ. 次デ之チ「グリセリン」浴二浸シ．溫度キ $180-190^{\circ} \mathrm{C}=$ 調節シツ、10 時 間二瓦ツテ加熱入ル。コレ等ノ操作八總テ紫田桂太敎授ノ方法二準據セルモノデアル。

斯ル「グリセリン熱分解ノ結果得タル褐色ノ液體キ险川須藤氏液體浸出器二カケテ 一書夜牛浸出シ.次デナホ褐色帶ビタル「グリセリン」溶液き. 逆流冷却裝置き具へ タル「コルベン」中ニテ。「クロロフォルム」ト共二加熱スル。

次ニ「クロロフォルム」キ除イタ「グリセリン」溶液二 3 倍量ノ蒸餾水キ加へ. とチ瑪瑙 球于有之几電氣的磨碎裝置二納メ 1 書夜研磨シ。析出物滤紙上二集メ. $37^{\circ} \mathrm{C}$ ，溫度 ル下二畺空乾燥スル。カクテ得タル灰白色粉末チ. 熱シタル Essigäther 二テ 2 書夜 浸出シ。次デ Aceton, Aethylalkohol, Methylalkobol, Eisessig デ順次津出シ。最 後)殘查八熱湯デ 1 書夜浸漬シタ。以上ノ如キ方法デ各分劃カラ結晶性物質チ得ル。

是等, 物質ノ化學反應き檢スルニ. Millon-, Biuret-, Hopkins-Cole-, Molisch-, Abderhalden-Schmidt-, Schwefelreaktion 等ハ何レモ陰性デ. 唯ダ Xanthoprotein 反應ハ「エーテル」浸出物ト「エチルアルコホル」浸出物トニ於テ(士)ノ程度デアッタ。 反之. Jaffe 反應八何レモ例外ナク頗ル顯著二陽性デアッテ、コレカラ推察スル時ハ 分解終末産物中二八、遊離 Amino-酸ヤ Peptide，如キモノハ存在セザルモノト見 ル可ク. 却テ Carbonyl 反應陽性ノAmino-酸失水物ノ存在が示サレテ居ルモノト見 
ル可キデアラウ。

著者八以上ノ如キ分劃中.「エーテル」「「アセトン」.「エチルフルコホル」ノ3浸出 物二就テ・ソノ抗原性き檢查スルコトトナシタ。

ソノ試驗管內抗原性二關シテハ. 抗馬家鬼血淸ト, 間ノ沈降反應. 補體結合反應 檢シタノデアルガ. 㥀重反復檢查セルニ拘ラズ. 何レモ皆陰性ノ成績二終ツタ。ソ， 術式ノ詳細ハ省略スルコトニスルガ. 此ノ呼究ニハ小橋茂穗博士ガ協力七ラレタコト 于附記スル。

次二カ、ルDiketopiperazin 體ト想定サルルモノノ生體內抗原性き检討セムトシテ. 家鬼キ種々ナ方法デ免度シテ見タ。時ニハ豚血清ナドョ Schlepper ノ意味デ添加シ タコトモアルガ. 結局斯ノ如キ虫度操作ニヨツテ得タ家鬼血清ハ、Diketopiperazin 體トモ特異的二反應モシナケレバ. 又馬血清トモ何等血清學的二證セラル可キ反應き 呈シテハ來ラナカツタ。佾ホスカ、ル物質ハ海猽二對シテ過敏抗原トシテノ作用モナ ク. 更二又馬血清キ以テ過敏性き賦與サレタ海猽二。靜脈內注射チ施スニ當ツテモ. 何等 Shock 症狀惹起スルコトモナカツタ。

上.上ノ賽驗キ次二 Kasein, Merk 二就テ反復シテ見タノデァルガ. 矢張り全ク同一 ノ結果キ得テ居ル。先ジ最初コノ Kasein キ以テ家鬼キ莬疫シ。 $5 \%$ Kasein.二對シ テソノ 1280 倍稀程迄沈降反應陽性ナル免度血清キ獲得シタガ. Kasein テ「グリセリ ン」熱分解セル後ノ各分劃ハ. 何レモコレト特殊ナ血清反應 チ呈スルコトモナイシ. 又是等ノ分劃中ノ Diketopiperazin ト想定七ラルル物質自身八, 生體內抗原トシテモ ソノ機能キ現ハシ得ナイモノデアルコトチ知リ得タ。

如斯次第デアルカラ. 是等 /賽驗成績キ一言二約ムレバ。 『蛋白質ョリ「グリセリン」 熱分解ノ結果得ラレタル Diketopiperazine ト見做サルル物質二八。試驗管內及ビ生 體內何レノ抗原性チモ認メ得ヌ』ト云フコトニナルデァラウ。

\section{第二章 化學的純粹ノ Diketopiperazin 卜其ノ抗原性二就テ}

第一章二於ケル實驗入抗原性ノ極メテ顯著ナル蛋白體ヨリ出發シテ:ソノ「グリセリ ン」攀分解ノ結果得ラレタ Diketopiperazin 誘導體卜想像七ラルルモノノ抗原性キ吟 味シタノデアルガ. 立デハ化學的純粹二得ラレタ Diketopiperazin 體二就テ. ソノ 抗原性ノ有無タ精查セムト企圖シタノデアル。

賽驗二使用シタ Diketopiperazin ハ Glycylalaninanhydrid デァッテ.えレハ內 野豐生博士二依ツテ Seidenfibroin カラ得ラレタモノデァル。ソノ製造方法ハ專ラ 
Ssadikow 及ビ Zelinsky 法ニ準據シタモノデ。元來兩氏ノ方法ハ $1 \%$ 稀硫酸キ以テ Seidenfibroin $7180^{\circ} \mathrm{C}=$ 加熱スルノデアルが. 內野氏ハ $0.15-0.175$ 定規稀硫酸ヨ 以テ $170^{\circ} \mathrm{C}=10$ 時間加熱シテ居心。次デ之キ中和シ低溫臭空二竟詰メル。然ラバ 水二不溶性，Glycyltyrosinanhydrid；結晶が析出スルカラコレタ滤別シ。母夜き Essigäther デ浸出スル。斯クテ Essigäther キ駱逐シテ得タル物質キ水二溶解シ.

Tierkohle キ以テ脫色シタル後少シク煮詰メル。コ、デヌ析出物ガフルガ.コレハ先 ニ落チザリシ Glycyltyrosinanhydrid ガ更二析出シタノデアルカラ.コレン更二落別 シ. 滤液ノ方八乾涸スルマデ煮詰メタ後溫「アルコホル」二溶解シ。次デえレォ冷却シ ア結晶タ析出セシメル。

コノ操作キ反復スルコト4回ニシテ得タル物質八. 元素分析. 分子量測定. 融點決 定等二依ツテ夫レガ純粹ナ Glycylalaninanhydrid デァルコトキ謢シ得ル。

例之 $\mathrm{C}_{5} \mathrm{H}_{8} \mathrm{O}_{2} \mathrm{~N}_{2}=128.1$ (實測值八 133.0)

\begin{tabular}{|c|c|c|c|}
\hline \multirow{4}{*}{$\mathrm{C}_{5} \mathrm{H}_{8} \mathrm{O}_{2} \mathrm{~N}_{2}$ 二對シ。 } & & 計算値 & 實測値 \\
\hline & C & $46.85 \%$ & $46.69 \%$ \\
\hline & $\mathrm{H}$ & $6.30 \%$ & $6.21 \%$ \\
\hline & $\mathrm{N}$ & $21.84 \%$ & $22.03 \%$ \\
\hline
\end{tabular}

\section{第一節 抗原溶液作製法泣 $=$ 免疫方法}

上述, Glycylalaninanhydrid ハ「アルカリ」性反應ニテハ分解セラレ易イカラ. 嚴 二中性又八稍 $、$ 酸性二保ツャウニ心掛ケタ。郎チ Glycylalaninanhydrid チ $0.85 \%$ 食 籃水 $=1 \%$ 割合二溶シ. $\mathrm{pH}=6.2$ タラシメ.コレチ每日又ハ 3 日ノ間隔キ以テ一群 , 正常家鬼 (體重 2200-2500 g ) 耳靜脈二注射シタ。ソノ每回ノ注射量ハ $1.0 \mathrm{ccm}$ 宛 デ. 10 回注射 施行シタカラ. Glycylalaninanhydrid，注射總量 $0.1 \mathrm{~g}=$ 上儿譯 デアルが, 家鬼八連日注射ノモノモ 3 日間隔ノモノモ。ソノ健康狀態八頗ル可良デ. 格別體重減少ナドト云フコトモ認メラレナカツタ。佾ホ他方 Kombinationsimmunisierung モ試ルコトトシタ。其ノ 1 ハGelatin キ添加シ.其ノ 2 八豚血清キ Schlepper トシテ加フルコトニシタモノデァル。前者ハ $1 \%$ Glycylalaninanhydrid 溶液二

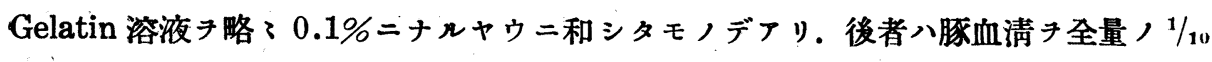
ニナィャウニ加へタモノデアル。注射ハ何レモ前ト同樣. 連日又ハ3 日ノ間隔キ以テ

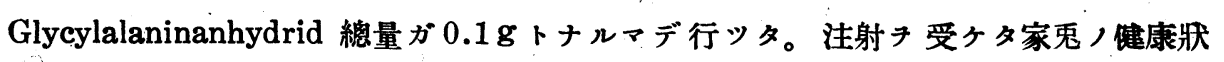
賭ハ矢張り可良デァル。 


\section{第二節 各種血清反應 ノ檢査}

第一項二述心゙タ方法デ免废サレタ家鬼ノ各群ハ. 何レモソノ最後ノ注射カラ 1 用日 目二全探血キ施サレタ。か、ル免疫血清キ以テ次ノ如キ血清反應キ施行シタ。

(1) 補體結合反應。

Browning 法二準據シテ行つ。抗原溶液八既二抗補體作用チ示サザル濃度ノ更二2 倍稀释以上ヨ用七テ居ルガ. 本反應ハ終二陽性ノ成績キ得ルニ至ラヌ。

(2) 沈降反應。

コレモ全ク陰性。

(3) 過敏应實驗。

a) 自働性過敏症。

Glycylalaninanhydrid = Gelatin 又八豚血清キ加へタ抗元溶液キ以テ海猽感作 シ ( 1 回又八數包注射キ行フ). 次デ 2-3-4 週ノ間二 Glycylalaninanhydrid 溶液 靜脈內二注射シテ見タガ. 總テ成績ハ陰性二終ッタ。但シ豚血清ノ加ハッテ居ルモ， 二就テハ. 豫メ豚血清ニテ除感作キ施シタ後二抗原再注射キ行ッタモノデアル。

b) 被働性過敏症。

Glycylalaninanhydrid+豚血清. 又八 Glycylalaninanhydrid+Gelatin キ以テ免疫

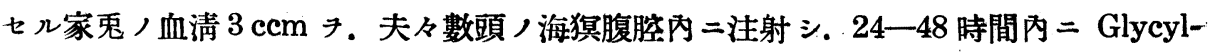
alaninanhydrid $50 \mathrm{mg}(1.5 \mathrm{ccm}$ 食監水中二含マシム) 静脈內二注射シテ見タガ. 異 狀丹認メタモノハ1頭モナイ。

以上ノ如ク樣々ニ骨チ折ツテ見タガ. 結局純粹, Diketopiperazin 二八抗原性タ 證明スルコトノ頗ル困難ナルキ學エタ次第デアル。

\section{第三章 總括卜結論}

以上第一章. 第二章ノ實驗き通覽スルト. Diketopiperazin 體ソレ自身ニ八抗原性 ハナイヤウニ見エル。尤モ第二章ノ實驗二用ヒタ化學的純粹ナ Diketopiperazin 八 Glycylalaninanhydrid デアッテ・ソレ以外ノモノニ就テ檢査シタ譯デハナイ。

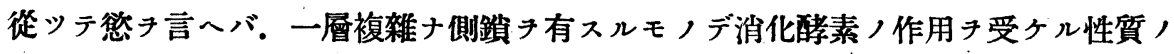
Diketopiperazin 誘導體二就テモ. 更二詳細ナ研究チスルナラバ. 第二章ノ研究ハ一 層完璧き期シ得ラレル譯デアラウガ.此ノ種ノ研究ハ決シテシカク容易ノコトデパ ルマイ。然シ何レニシテモ第一章ノ實驗ニ於テハ。执原性チ有スル天然ノ蛋白質カラ 
Diketopiperazin ト想定サルルモノ人湶合物チ得テ・ソレノ抗原機能卜抗原作用トチ 壃重二檢查シテ．何レモ陰性ナルコトタ證明シテオイタノデァルカラ．コレト第二章 ノ兴驗トチ前後照應セシメルナラバ。蛋白質構造中二Diketopiperazine アリトスル モ. 蛋白質ノ抗原性ハソノ部ニハ支配サレナイデアラウト推定シ得ル。

斯ル次第故. 今包, 研究カラシテ. 蛋白質ノ終末分解産物トシテ報告セラレタモノ 八, 何しモ抗原性デ發揮スル所ガナイト謂七得ハデアラウ。 故二結論トシテハ，蛋白質ノ終末分解库物トシテ得ラレタモノデ．構造化學上確然 タルモノ. 換言スレバ.Amino-酸. Polypeptide 及ビ Diketopiperazine ニハ何レモ 抗原性フ認メ得ヌトイフコトニナル。

附記。本研究ノ成績ハ上上ノ如ク簡潔キ旨トシテ記載シタノデァルガ. 實ハ多クノ 人ノ協力二依ツタモノデァルコトォ明ニシテ置キ度イ。殊二小橋茂穗博士. 高橋義夫

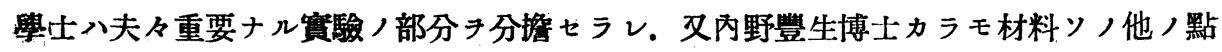

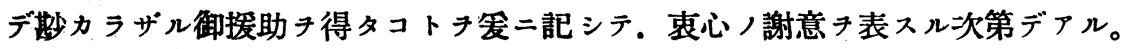

\section{文都}

1) Keita Shibata, Depolymerisation von Proteinstoffen und Wiederaufbau der eiweissartigen Substanzen aus den Spaltprodukten., Acta Phytochimica, Vol. II, No. 2. (1925).

2）佐々木隆興，輓近蛋白化學／研究. 日本生化學會會報. 第二卷. 第四一第五號. 1927.

3) Toyoo Uchino, Untersuchungen uber den partiellen Abbau des Seidenfibroins. The Journal of Biochemistry, Vol. 20, No. 1, July, 1934.

4）柿內三郎，生體膠筫二就テ. 日本生化學會會報. 第十三替. 第四號. (昭和十三年十一月). 